\title{
Effect of therapeutic doses of antibiotics in the diet on the digestibility and caecal fermentation in growing rabbits
}

\author{
Leticia AbeCia, Joaquim BALCELLS*, Manuel FondEVILA, \\ Álvaro BELENGUER, Lucía CALLEJA
}

\begin{abstract}
Departamento de Producción Animal y Ciencia de los Alimentos, Facultad de Veterinaria, Universidad de Zaragoza, Miguel Servet 177, 50013 Zaragoza, Spain
\end{abstract}

(Received 27 June 2003; accepted 7 April 2005)

\begin{abstract}
The effect of two doses of antibiotics, chlortetracycline (200 and 400 ppm, L-CTC and $\mathrm{H}-\mathrm{CTC}$ ) and zinc bacitracin (50 and $100 \mathrm{ppm}, \mathrm{L}-\mathrm{BAC}$ and H-BAC) over a control diet (no antibiotics) was studied with five groups of 8 New Zealand growing male rabbits $(1455 \pm 13.9 \mathrm{~g}$; 49 days of age). The diets were given "ad libitum" for 21 days of the experiment, consisting of $14 \mathrm{~d}$ of adaptation and $7 \mathrm{~d}$ of a digestibility trial and urine and caecotrophs collection. At the end of the experiment, four animals per treatment were slaughtered, and caecal parameters were measured. Apparent dry matter, organic matter and neutral detergent fibre digestibilities increased with bacitracin addition compared with the control (in $0.022,0.018$ and 0.048 units; $P=0.03,0.06$ and 0.03 , respectively). CTC did not affect the referred parameters. Urinary purine derivatives (PD) excretion and duodenal flow of purine bases (PB) did not evidence differences between the control and tested antibiotic although a high dose of bacitracin depressed both urinary PD and duodenal flow of PB in relation to L-BAC. Medicated diets did not affect $\mathrm{N}$ recycling regardless of the method of measurement.
\end{abstract}

rabbit / antibiotics / caecum / purine derivatives

Résumé - Addition d'antibiotiques à doses thérapeutiques dans le régime de lapins en croissance. Effet sur la digestibilité et la fermentation caecale. L'effet de deux doses d'antibiotiques, chlortétracycline (200 et 400 ppm, L-CTC et H-CTC) et bacitracine-zinc (50 et $100 \mathrm{ppm}, \mathrm{L}-\mathrm{BAC}$ et H-BAC), par rapport à un régime témoin (sans antibiotique) a été étudié sur 5 groupes de 8 lapins mâles en croissance de race New Zealand (1455 $\pm 13,9 \mathrm{~g} ; 49$ jours d'âge). Les animaux ont été nourris ad libitum pendant une période expérimentale de 21 jours, qui comptait une période d'adaptation de 14 jours et une période de mesure de la digestibilité et de collecte des urines et des caecotrophes de 7 jours. À la fin de l'expérience, 4 animaux par traitement ont été abattus, et les paramètres caecaux évalués. Les digestibilités de la matière sèche, de la matière organique et des fibres (NDF) ont été augmenté avec l'addition de bacitracine comparativement au témoin (de $0,022,0,018$ et 0,048 unité $; P=0,03,0,06$ et 0,03 , respectivement). CTC n'a affecté aucun paramètre. L'excrétion urinaire de dérivés des bases puriques (PD) et le flux duodénal de bases puriques (PB) n’ont pas été différents entre le régime témoin et les régimes avec antibiotiques, bien que la dose

* Corresponding author: balcells@posta.unizar.es 
élevée de bacitracine (H-BAC) ait diminué les PD urinaires et le flux duodénal de PB par rapport à L-BAC. Quelle que soit la méthode de mesure, les régimes avec antibiotiques n'ont pas affecté le recyclage de l'azote.

lapin / antibiotique / caecum / dérivés puriques

\section{INTRODUCTION}

Intensive rabbit production is commonly restricted by the susceptibility of this species to digestive disorders. Inclusion of antibiotics at sub-therapeutic doses as dietary additives was widespread in practical conditions in order to prevent proliferation of pathogens in the digestive tract, thus reducing the immune response and increasing the availability of nutrients, and consequently improving productive performances. The efficacy of antibiotics as growth promoters in other species, such as pigs, is well documented [10], but currently this practice is forbidden in Europe. However, the use of medicated feeds for therapeutic purposes is still allowed in situations of disease in practical conditions and therefore information about the possible side-effects of this practice is necessary.

Although the effect of antibiotic substances is mainly focused on the small intestine, it can be extended to the whole digestive tract, modifying the fermentation processes in the hind-gut in order to improve their contribution to rabbit metabolism [18] if they are not previously absorbed.

The objective of this experiment was to study the effect of two antibiotics of common use in rabbit medicine (chlortetracycline and zinc bacitracin) included at therapeutic doses on digestibility, caecal environment and microbial-N recycling in growing rabbits.

\section{MATERIALS AND METHODS}

\subsection{Animals and diets}

Forty White New Zealand healthy male rabbits of $1465 \pm 13.9 \mathrm{~g}$ weight and aged 49 days were used. The animals were housed in individual cages $(78 \times 49 \times 31 \mathrm{~cm})$ provided with a feeder and suckling drinker in an environmentally controlled barn (18$24^{\circ} \mathrm{C}, 12 \mathrm{~h}$ light per day). The experimental diet was formulated with $\left(\mathrm{g} \cdot \mathrm{kg}^{-1}\right)$ barley, 440; alfalfa hay, 240; sugar beet pulp, 82; soya bean meal, 150; straw, 60 and a vitamin-mineral mixture, 28 . The gross chemical composition of the diet $\left(\mathrm{g} \cdot \mathrm{kg}^{-1}\right.$ dry matter, DM) was the following: organic matter (OM), 910; crude protein (CP), 170; neutral detergent fibre (NDF), 269; acid detergent fibre (ADF), 154 and acid detergent lignin (ADL), 25. Prior to mixing and pelleting, the diet was supplemented with one of two commonly used antibiotics (chlortetracycline, CTC or zinc bacitracin, BAC) added at two therapeutic levels, low and high. Thus, the experimental treatments were the following: $200 \mathrm{ppm} \mathrm{CTC} \mathrm{(L-CTC);} 400 \mathrm{ppm}$ CTC (H-CTC); 50 ppm BAC (L-BAC); 100 ppm BAC (H-BAC); and a control (no added antibiotics). The rabbits were randomly allocated to the five experimental diets (8 animals per diet) in successive periods.

\subsection{Experimental procedures}

Each experimental period lasted for twenty-one days, fourteen days for adaptation to the experimental diets, when rabbits were penned individually, and seven days of a collection period, when the rabbits were housed in metabolic cages for faeces and urine collection. The animals were weighed once weekly and at the beginning and at the end of each experimental period. The following schedule was adopted during the control period: adaptation to the metabolic cage on days 1 and 2; digestibility and urine collection on days 3 to 6 ; and fitting neck collars (50 mm i.d. and $270 \mathrm{~mm}$ o.d., weighing aprox. $67 \mathrm{~g}$ ) for preventing caecotrophy 
on day 7. At the end of the first, third, fifth and seventh control periods, the animals were slaughtered between 8:00 and 12:00 hours, resulting in four slaughtered rabbits per experimental treatment.

\subsection{Sample collection}

Urine was collected over $50 \mathrm{~mL}$ of $10 \%$ $\mathrm{H}_{2} \mathrm{SO}_{4}$ (to keep $\mathrm{pH}<3$ ). Daily excreted urine was diluted to a litre with distilled water to avoid uric acid precipitation, then sampled $\left(200 \mathrm{~mL}\right.$ ) and stored at $-20{ }^{\circ} \mathrm{C}$. The faeces were collected daily, individually pooled and stored at $-20^{\circ} \mathrm{C}$. Caecotrophs were collected together with hard faeces, separated manually and then frozen at $-20{ }^{\circ} \mathrm{C}$. The animals were slaughtered by cervical dislocation, then were dissected and the caecum was excised and weighed. The $\mathrm{pH}$ of the caecal content was determined with a glass electrode $\mathrm{pH}$-meter. Samples for ammonia and microbial concentration were taken as specified in Belenguer et al. [4].

\subsection{Chemical and microbiological analyses}

DM of feeds and total collection of faeces and caecotrophs after thawing was determined by drying at $60{ }^{\circ} \mathrm{C}$ to constant weight. Once dried, the samples were ground to $1 \mathrm{~mm}$ particle size for the remaining analysis. Concentration of $\mathrm{OM}$ and $\mathrm{N}$ was determined by ashing at $550{ }^{\circ} \mathrm{C}$ for 8 hours and by the Kjeldhal method, respectively. Proportions of NDF, ADF and ADL were analysed according to the procedure described by Van Soest et al. [20] after a pre-treatment with amylase and discounting the residual ashes. Caecal ammonia was determined using the method proposed by Chaney and Marbach [8] and urinary purine derivatives (allantoin, uric acid, PD) and creatinine were analysed by reverse-phase HPLC, using two Spherisorb C-18 ODS-2 $(4.6 \times 250 \mathrm{~mm})$ columns, according to the technique described by Balcells et al. [2].
Total, cellulolytic and amylolytic bacterial concentrations were determined by the most probable number procedure in triplicate liquid media tubes. Tubes for amylolytic bacterial counts included maize starch as the only substrate and total and cellulolytic bacteria were cultivated simultaneously following Dehority et al. [12]. The tubes were inoculated with serial dilutions $\left(10^{-5}\right.$ to $10^{-10}$ for total and cellulolytic bacteria and $10^{-6}$ to $10^{-10}$ for amylolytic bacteria) and incubated for 14 and 7 days, respectively. Growth of cellulolytic bacteria was determined by visual loss of cellulose and that of total and amylolytic bacteria by $\mathrm{pH}$ changes.

\subsection{Calculations and statistical analyses}

Duodenal flow of purine bases and microbial protein was calculated following Balcells et al. [2] with the modification proposed by Belenguer [5].

The treatments were compared statistically using the SAS package (SAS, 2002) [19]. For the study of the productive parameters, digestibility and caecotrophs and PD excretion, the effect of the period was also included in the analyses and the treatment effect was contrasted against an error with 28 degrees of freedom (d.f.). Since the period effect did not reach statistical significance $(\mathrm{F}<1)$ when caecal parameters were analysed, variation was included in the error term and the treatment effect was contrasted against the residual term (15 d.f.). In both cases, non-orthogonal contrasts were established to compare treatment differences $(P<0.05)$ :

$\mathrm{C}_{1}$ : Control vs. bacitracin

$\mathrm{C}_{2}$ : Control vs. chlortetracycline

$\mathrm{C}_{3}$ : Bacitracin vs. chlortetracycline

$\mathrm{C}_{4}$ : High vs. low doses of bacitracin.

For MN recycling, the results were tested as a split plot design and antibiotic and doses effects were the main plots considered, (contrasted against animal error term) 
Table I. Effect of diet supplementation with two antibiotics, Bacitracin and Chlortetracycline at two therapeutic doses (low, L and high, H) on the digestibility of dry matter (DMD), organic matter (OMD) and neutral detergent fibre (NDFD) in growing rabbits fed ad libitum.

\begin{tabular}{|c|c|c|c|c|c|c|c|c|c|c|}
\hline & \multirow[b]{2}{*}{ Control } & \multicolumn{2}{|c|}{ Chlortetracycline } & \multicolumn{2}{|c|}{ Bacitracin } & \multirow[b]{2}{*}{ SEM } & \multirow[b]{2}{*}{$\mathrm{C}_{1}$} & \multirow[b]{2}{*}{$\mathrm{C}_{2}$} & \multirow[b]{2}{*}{$\mathrm{C}_{3}$} & \multirow[b]{2}{*}{$\mathrm{C}_{4}$} \\
\hline & & L-CTC & H-CTC & L-BAC & H-BAC & & & & & \\
\hline DMD & 0.686 & 0.689 & 0.697 & 0.697 & 0.718 & 0.0106 & $*$ & ns & $\mathrm{ns}$ & ns \\
\hline OMD & 0.696 & 0.694 & 0.703 & 0.703 & 0.724 & 0.0104 & $\mathrm{t}$ & $\mathrm{ns}$ & ns & ns \\
\hline NDFD & 0.235 & 0.247 & 0.236 & 0.280 & 0.286 & 0.0243 & * & $\mathrm{ns}$ & $\mathrm{ns}$ & ns \\
\hline
\end{tabular}

SEM: Standard error of means; Contrast: $\mathrm{C}_{1}$ : Control vs. bacitracin, $\mathrm{C}_{2}$ : Control vs. chlortetracycline, $\mathrm{C}_{3}$ : Bacitracin vs. Chlortetracycline, $\mathrm{C}_{4}$ : High vs. low bacitracin doses.

Statistical significance of treatment effect: *: $P<0.01$; t: $P \leq 0.1$.

whereas the method (caecotrophs vs. PD excretion) was taken as a sub-plot (contrasted against the residual error).

\section{RESULTS AND DISCUSSION}

Initial and final average rabbit weight were $1465 \pm 36.1$ and $2016 \pm 53.9$ with a daily growth rate of $30 \mathrm{~g} \cdot \mathrm{d}^{-1}$. Average intake of DM and DOM were 114.8 \pm 6.23 and $74.10 \pm 3.82$, respectively.

\subsection{Effect of antibiotic supplementation on digestibility}

The apparent digestibilities of the diets are shown in Table I and the coefficients were within the range reported in the literature for similar diets, either in DMD or OMD [4, 16] and also regarding the low fibre utilisation in this species $(0.22-0.27$; $[4,15])$. On average, the diets including bacitracin improved DM, OM and NDF apparent digestibility in $0.022(P<0.05)$, $0.018(P<0.1)$ and $0.048(P<0.05)$ points, respectively compared to the control diet. The positive response to bacitracin inclusion was mainly caused by the higher doses of inclusion. In the existing literature, the improvement in digestibility has been explained either by a control of pathogenic micro-organisms, by an increase in the efficiency of fibre utilisation [9] or by changes in the intestinal mucosa that would improve nutrient absorption through the caecum wall [17]. The latter hypothesis is supported by changes observed in duodenal mucosa of piglets given bacitracin $[6,11]$. Our data cannot clarify this point since the presence of pathogens or the structure of intestinal mucosa were not studied. In contrast, diet digestibility was not affected by the addition of chlortetracycline.

\subsection{Characterisation of caecal fermentation}

Table II shows the treatment means for caecum weight, caecal environmental parameters ( $\mathrm{pH}$ and ammonia concentration) and microbial counts (concentration of total, amylolytic and cellulolytic bacteria). No treatment effect on total caecum or its content weight was detected. Caecum weight averaged $134 \mathrm{~g}$, representing about $9 \%$ of the animal weight and caecal content weight was $95 \mathrm{~g}$. At the slaughtering conditions of this experiment, neither differences in $\mathrm{pH}$ (average 5.91) nor in ammonia concentration $\left(34.5 \mathrm{mg} \cdot \mathrm{L}^{-1}\right)$ among treatments were detected.

Total bacterial concentration in caecal content was not significantly affected by 
Table II. Effect of diet supplementation with two antibiotics, Bacitracin and Chlortetracycline at two therapeutic doses (low, $\mathrm{L}$ and high, $\mathrm{H}$ ) on total caecum and caecal content weight (g), on pH and $\mathrm{NH}_{3}$ concentration $\left(\mathrm{mg} \cdot \mathrm{L}^{-1}\right)$, and on concentrations of total $\left(\times 10^{8}\right.$ per $\left.\mathrm{g}\right)$, amylolytic $\left(\times 10^{8}\right.$ per $\left.\mathrm{g}\right)$ and cellulolytic $\left(\times 10^{5}\right.$ per $\left.\mathrm{g}\right)$ caecal bacteria in growing rabbits fed ad libitum.

\begin{tabular}{|c|c|c|c|c|c|c|c|c|c|c|}
\hline & \multirow[b]{2}{*}{ Control } & \multicolumn{2}{|c|}{ Chlortetracycline } & \multicolumn{2}{|c|}{ Bacitracin } & \multirow[b]{2}{*}{ SEM } & \multirow[b]{2}{*}{$\mathrm{C}_{1}$} & \multirow[b]{2}{*}{$\mathrm{C}_{2}$} & \multirow[b]{2}{*}{$\mathrm{C}_{3}$} & \multirow[b]{2}{*}{$\mathrm{C}_{4}$} \\
\hline & & $\begin{array}{l}\text { L-CTC } \\
\text {-CT }\end{array}$ & H-CTC & L-BAC & H-BAC & & & & & \\
\hline Caecum & 134 & 142 & 145 & 119 & 132 & 17.6 & $\mathrm{~ns}$ & $\mathrm{~ns}$ & ns & $\mathrm{ns}$ \\
\hline Caecum content & 96 & 103 & 103 & 81 & 94 & 17.2 & $\mathrm{~ns}$ & ns & ns & ns \\
\hline $\mathrm{pH}$ & 5.87 & 5.92 & 5.69 & 6.07 & 5.97 & 0.145 & $\mathrm{~ns}$ & $\mathrm{~ns}$ & ns & ns \\
\hline $\mathrm{NH}_{3}$ & 23.6 & 23.9 & 31.5 & 43.9 & 49.4 & 13.87 & $\mathrm{~ns}$ & $\mathrm{~ns}$ & ns & ns \\
\hline Total & 21.1 & 53.8 & 32.1 & 19.0 & 15.9 & 16.42 & $\mathrm{~ns}$ & $\mathrm{~ns}$ & ns & ns \\
\hline Amylolytic & 5.8 & 20.3 & 23.5 & 20.3 & 7.3 & 8.77 & $\mathrm{~ns}$ & $*$ & $\mathrm{~ns}$ & ns \\
\hline Cellulolytic & 16.0 & 6.6 & 7.5 & 17.7 & 2.3 & 9.26 & ns & $\mathrm{ns}$ & ns & ns \\
\hline
\end{tabular}

SEM: Standard error of means; Contrast: $\mathrm{C}_{1}$ : Control vs. bacitracin, $\mathrm{C}_{2}$ : Control vs. chlortetracycline, $\mathrm{C}_{3}$ : Bacitracin vs. Chlortetracycline, $\mathrm{C}_{4}$ : High vs. low bacitracin doses.

*: Statistical significance of treatment effect $P<0.01$.

either chlortetracycline or bacitracin compared to the control. However, total counts with CTC diets were numerically higher than those with the control diet $(P=0.14)$, and this was reflected in a higher amylolytic bacterial concentration with the former $(P<0.05)$. No treatment effects were detected for cellulolytic bacterial counts despite the previously mentioned increase in NDF digestibility with bacitracin.

It is necessary to point out the high magnitude of the error term, inherent to bacterial counts in the fermentation compartments, which avoids establishing a sound hypothesis. In relation to the existing literature, no information is available about the effect of dietary antibiotic supplementation on caecal microflora. Total and cellulolytic bacterial concentrations were similar to those previously observed [4], but lower than the results reported by Emaldi et al. [13] or Boulahrouf et al. [7].

\subsection{Duodenal flow and urinary excretion of purine compounds}

Allantoin was the main urinary PD (Tab. III) accounting for about 0.92 of total PD excreted in the urine, whereas uric acid accounted for the remaining 0.08 , with these proportions being independent of the experimental treatments. Urinary PD excretion was not affected by antibiotic supply although it was decreased with the high level of bacitracin supplementation $(P<0.05)$. Duodenal flow of PB reflected those variations detected in urinary PD excretion. However, a higher dietary PB flow was detected in the rabbits fed bacitracin compared to those receiving the chlortetracycline diets because of numerical differences in DM intake between the diets (110.5 vs. $116.0( \pm 6.2) \mathrm{g} \cdot$ day $^{-1}$, respectively).

In the rabbit, as a caecotrophagic animal, duodenal purine bases come from two 
Table III. Effect of diet supplementation with two antibiotics, Bacitracin and Chlortetracycline at two doses (low, $\mathrm{L}$ and high, $\mathrm{H}$ ) on urinary excretion of purine derivatives and estimated values of duodenal purine bases flow $\left(\mathrm{mmol} \cdot \mathrm{W}^{-0.75}\right)$ in growing rabbits.

\begin{tabular}{|c|c|c|c|c|c|c|c|c|c|c|}
\hline & \multirow[b]{2}{*}{ Control } & \multicolumn{2}{|c|}{ Chlortetracycline } & \multicolumn{2}{|c|}{ Bacitracin } & \multirow[b]{2}{*}{ SEM } & \multirow[b]{2}{*}{$\mathrm{C}_{1}$} & \multirow[b]{2}{*}{$\mathrm{C}_{2}$} & \multirow[b]{2}{*}{$\mathrm{C}_{3}$} & \multirow[b]{2}{*}{$\mathrm{C}_{4}$} \\
\hline & & L-CTC & H-CTC & L-BAC & H-BAC & & & & & \\
\hline Total PD & 1.23 & 1.22 & 1.30 & 1.44 & 1.17 & 0.016 & ns & ns & ns & $*$ \\
\hline Allantoin & 1.15 & 1.12 & 1.20 & 1.33 & 1.08 & 0.014 & ns & ns & ns & $*$ \\
\hline Uric acid & 0.08 & 0.10 & 0.10 & 0.12 & 0.09 & 0.001 & ns & ns & ns & ns \\
\hline Total PB & 1.83 & 1.83 & 1.93 & 2.12 & 1.79 & 0.037 & ns & ns & ns & $*$ \\
\hline Dietary PB & 0.71 & 0.64 & 0.64 & 0.76 & 0.71 & 0.003 & ns & ns & $*$ & ns \\
\hline Microbial PB & 1.18 & 1.23 & 1.35 & 1.46 & 1.10 & 0.041 & ns & $\mathrm{ns}$ & ns & * \\
\hline
\end{tabular}

SEM: Standard error of means; Contrast: $\mathrm{C}_{1}$ : Control vs. bacitracin, $\mathrm{C}_{2}$ : Control vs. chlortetracycline, $\mathrm{C}_{3}$ : Bacitracin vs. Chlortetracycline, $\mathrm{C}_{4}$ : High vs. low bacitracin doses.

*: Statistical significance of treatment effect $P<0.01$.

sources: dietary and caecotrophy sources, with the latter making the highest contribution (Tab. III). Considering that no changes in dry matter intake were registered the absence of differences in duodenal PB flow indicates that antibiotic supply does not significantly reduce caecotrophs production and/or intake. Moreover, our results suggest, no quantitative changes in microbial production except for the high dose of bacitracin, which shows a small but significant $(P<0.05)$ decrease in caecotrophs production. With the caution derived from the small number of experimental animals, bacitracin seems to have a double effect, it improves nutrient digestibility and at its highest dose it reduces to some extent urinary excretion of PD. The latter may be caused by changes in either PB metabolism or caecum microbial yield, although such an effect was not detected when estimated by caecotrophs collection.

\subsection{Caecal microbial yield}

Caecotrophagy is the physiological strategy of rabbits to recycle caecal microbial protein in order to improve protein utilisation, thus excretion of caecotrophs should be a tool to estimate microbial yield in the rabbit caecum. Average amounts of DM and crude protein excreted as caecotrophs are shown in Table IV. Mean DM excretion as caecotrophs was $16.3 \mathrm{~g} \cdot \mathrm{d}^{-1}$ and no significant effect of the experimental treatments was detected. Values were within the range obtained previously in our own lab $\left(12.8-22.1 \mathrm{~g} \cdot \mathrm{d}^{-1},[4]\right)$ and others (15$30 \mathrm{~g} \cdot \mathrm{d}^{-1}$ with an average value of 20.8 [14]).

Indirect methodology based on urinary excretion of PD may overcome the stress and the consequent decrease in voluntary intake induced by the collar fitting [3, 4]. A comparison of using neck collar and urinary PD excretion as methods to estimate caecotrophs production is presented in Table IV.

Split-plot analysis of variance reflects a significant difference due to the methodology employed, with lower values derived from collar fitting than those obtained from urinary PD [0.63 vs. $1.53 \mathrm{~g} \cdot \mathrm{d}^{-1}( \pm 0.018)$; $P<0.005]$ in agreement with previous studies comparing both procedures [4]. Despite that, and regardless of the methodology, medicated diets had no effect on MN recycling.

However, relevant qualitative changes in the caecal bacteria population have been observed by dietary antibiotic addition [1] whereas bacitracin promotes a similar bacterial population as the control and that with chlortetracycline was clearly different. A 
Table IV. Effect of diet supplementation with two antibiotics, Bacitracin and Chlortetracycline at two therapeutic doses (low, L and high, H) on dry matter (DMcec; $\mathrm{g} \cdot \mathrm{d}^{-1}$ ) and crude protein (CPcec; $\mathrm{g} \cdot \mathrm{d}^{-1}$ ) excretion as caecotrophs and microbial nitrogen $(\mathrm{MN})$ recycling calculated either by caecotrophs collection after collar fitting (CF) or alternatively using urinary purine derivatives (PD) excretion as an indirect index.

\begin{tabular}{|c|c|c|c|c|c|c|c|c|c|c|}
\hline & \multirow[b]{2}{*}{ Control } & \multicolumn{2}{|c|}{ Chlortetracycline } & \multicolumn{2}{|c|}{ Bacitracin } & & \multicolumn{4}{|c|}{ Contrasts $(P)$} \\
\hline & & L-CTC & H-CTC & L-BAC & H-BAC & & SEM & $\mathrm{C} 1$ & $\mathrm{C} 2$ & $\mathrm{C} 3$ \\
\hline DMcec & 17.0 & 17.8 & 14.5 & 16.9 & 16.4 & & 2.25 & ns & ns & ns \\
\hline CPcec & 4.98 & 5.82 & 3.83 & 5.96 & 5.35 & & 0.804 & $\mathrm{~ns}$ & $\mathrm{~ns}$ & ns \\
\hline \multirow{2}{*}{\multicolumn{2}{|c|}{ MN Recycling Control }} & L-CTC & H-CTC & L-BAC & H-BAC & SEM1 & SEM2 & $M$ & $\mathrm{C} 1$ & $\mathrm{C} 2$ \\
\hline & & & & & & 0.039 & 0.018 & $* * *$ & $\mathrm{~ns}$ & ns \\
\hline $\mathrm{CF}$ & 0.58 & 0.74 & 0.48 & 0.72 & 0.66 & & & & & \\
\hline PD & 1.42 & 1.48 & 1.61 & 1.78 & 1.35 & & & & & \\
\hline
\end{tabular}

SEM: Standard error of means; $\mathrm{SEM}_{1}$ and $\mathrm{SEM}_{2}$ : standard error for the animal and error term for a splitplot design; Method $(\mathrm{M})$ and Treatment Contrast $(\mathrm{C})$ : $\mathrm{C}_{1}$ : Control vs. bacitracin, $\mathrm{C}_{2}$ : Control vs. chlortetracycline, $\mathrm{C}_{3}$ : Bacitracin vs. Chlortetracycline.

*: Statistical significance of method (M) or treatment effect (C) $P<0.01$.

long-term adaptation of the antibiotic resistant population might explain that qualitative changes in the caecum population were not reflected in final caecotrophs production.

\section{ACKNOWLEDGEMENTS}

This work was financed by Agribrands Europe, España, S.A., through the Project PTR 95/0405-OP. Thanks are given to the Servicio de Apoyo a la Investigación (Universidad de Zaragoza).

\section{REFERENCES}

[1] Abecia L., McEwan N.R., Newbold C.J., Fondevila M., Balcells J., Molecular profiling of the major bacterial species in the rabbit caecum as affected by therapeutical doses of antibiotics, in: 8th World Rabbit Congress, Puebla, Mexico, 2004, Abstracts Proceedings, p. 63.

[2] Balcells J., Guada J.A., Peiró J.M., Parker D.S., Simultaneous determination of allantoin and oxypurines in biological fluids by highperformance liquid chromatography, J. Chromatogr. 575 (1992) 153-157.
[3] Balcells J., Ganuza J.M., Pérez J.F., MartínOrúe S.M., Gonzalez Ronquillo M., Urinary excretion of purine derivatives as an index of microbial-nitrogen intake in growing rabbits, Brit. J. Nutr. 79 (1998) 373-380.

[4] Belenguer A., Balcells J., Fondevila M., Torre C., Caecotrophes intake in growing rabbits estimated either from urinary excretion of purine derivatives or from direct measurement using animals provided of neck collar: Effect of type and level of dietary carbohydrate, Anim. Sci. 74 (2002) 135-144.

[5] Belenguer A., Microbial nitrogen absorption in growing rabbits and lactating does in relation to type of dietary carbohydrate supply [Absorción de nitrógeno microbiano en conejos en crecimiento y hembras en lactación en realción con las variaciones en el tipo de carbohidrato suministrado en la ración], Ph.D. Thesis, University of Zaragoza, 2004.

[6] Bolduan G., Feeding weaner pigs without in feed antibiotics, in: Lyons T.P., Jacques K.A. (Eds.), Proceedings of Alltech 15th Annual Symposium, Nottingham University Press, Nottingham, United Kingdom, 1999, pp. 223230.

[7] Boulahrouf A., Fonty G., Gouet Ph., Establishment, counts and identification of the fibrolytic microflora in the digestive tract of the rabbit. Influence of feed cellulose content, Curr. Microbiol. 22 (1991) 21-25.

[8] Chaney A.L., Marbach E.P., Modified reagents for the determination of urea and ammonia, Clin. Chem. 8 (1962) 131-142. 
[9] Cheeke P.R., Rabbit feeding and nutrition, Jovanovich Publishers, Academic Press, Inc., Marcourt Brace, 1987.

[10] Cromwell G.L., Antimicrobial agents, in: Miller E.R., Ullrey D.E., Lewis A.J. (Eds.), Swine nutrition, Butterworth-Heinemann, Boston, USA, 1991, pp. 297-314.

[11] Decuypere J., Debrun M., Dierick N., Influence of buffering capacity of feed on the prececal digestibility in pigs, in: Laplace J.P., Fevrier C., Barbeau A. (Eds.), Proceedings of the 7th International Symposium on Nutritional Physiology of Pigs, Saint Malo, France, 1997, pp. 391-394.

[12] Dehority B.A., Tirabasso P.A., Grifo A.P., Most-probable number procedures for enumerating ruminal bacteria, including the simultaneous estimation of total and cellulolytic numbers in one medium, Appl. Environ. Microb. 55 (1989) 2789-2792.

[13] Emaldi O., Crociani F., Matteuzzi D., A note on the total viable counts and selective enumeration of anaerobic bacteria in the caecal content, soft and hard faeces of rabbit, J. Appl. Bacteriol. 46 (1979) 169-172.

[14] Fraga M.J., Protein Digestion, in: De Blas C., Wiseman J. (Eds.), The Nutrition of the rabbit,
CAB Publishing, Wallingford, UK, 1998, pp. 39-54.

[15] García J., Carabaño R., Pérez-Alba L., de Blas J.C., Effect of fiber source on neutral detergent fibre digestion and caecal traits in rabbits, in: Lebas F. (Ed.), Proceedings of the 6th World Rabbit Congress, Association Française de Cuniculture, Lempdes, France, 1996, pp. 75-180.

[16] Gidenne T., Pérez J.M., Effect of dietary starch origin on digestion in the rabbit. 2 . Starch hydrolysis in the small intestine, cell wall degradation and rate of passage measurements, Anim. Feed Sci. Technol. 42 (1993) 249-257.

[17] King J.O.L., The feeding of zinc bacitracin to growing rabbits, Vet. Rec. 99 (1976) 507508.

[18] Marty J., Vernay M., Absorption and metabolism of the volatile fatty acids in the hindgut of the rabbit, Brit. J. Nutr. 51 (1984) 265-277.

[19] SAS, User's Guide: Statistics, Version 8, SAS Institute Inc., Cary, NC, 2000.

[20] Van Soest P.J., Robertson J.B., Lewis R.A., Methods for dietary fiber, neutral detergent fiber and non starch polysaccharides in relation to animal nutrition, J. Dairy Sci. 71 (1991) 3583-3597. 